\title{
Language Education in Primary Schools in Nigeria: Contemporary Issues and New Direction
}

\author{
Musa Roselyn Jummai \\ Faculty of Education, Delta State University, Abraka. Nigeria
}

\begin{abstract}
The Federal Government of Nigeria in the National Policy on Education (2004), has spelt out the aims of Primary Education. Being the foundation for formal schooling, this paper posits that the effective tool for the appropriate achievement of quality education at this level is Language. The paper indentifies some contemporary issues like the multi-lingual problem, poor policy implementation, poor teacher quality and poor access to curriculum materials, as challenges. It suggests a search for new direction towards the development of the orthographies of indigenous languages, provision of regular and effective professional capacity development opportunities for classroom teachers and greater and sustained attention to the implementation of the core language education policy.
\end{abstract}

\section{Introduction}

Primary or basic education is the first level of education which a child undergoes before he/she moves on to the other levels. It is the bottom line education upon which every other education whether formal, informal or non-formal can be built without which any educational structure erected will not have chances of success. The core objectives of primary education in Nigeria, are the universalization of access and quality in the delivery. Other objectives include, inculcating in the school children permanent literacy, numeracy and the ability to communicate effectively. To this end, the Federal Government of Nigeria (9) recommends that:

Basic education shall be

9 year duration comprising

6 years of primary education and

3 years of junior secondary education.

It shall be free and compulsory.

One very vital tool necessary for humans to influence change, tackle hunger, and poverty is language. It is a component of culture along with other entities like values, norms and beliefs. An important difference between man and other animals is that man is psychologically and sociologically more flexible than other animals. Man alone is capable of controlling his environment and himself using language as a medium. For any meaningful communication to take place between man and man, therefore this all important tool must be effectively used.

The primary school in Nigeria is the foundation for formal school learning with the entry age for children at age 6 . This level of education stands as the pillar of school based teaching and learning which, according to Maduewesi and Eguabor [13] taps and root into the millennium development goals (MDGs) of:

- Eradicating extreme poverty and hunger;

- Achieving universal basic education;

- $\quad$ Promoting gender equality;

- Reducing child mortality;

- Combating HIV/AIDS, malaria and other diseases; and

- Ensuring environmental sustainability.

These lofty goals have implication for inculcating in the citizen the right type of values and attitudes for his life- long survival and that of his society and these values are enshrined in language..

\section{Aims of primary education in Nigeria}

To achieve functional primary education in Nigeria, the Federal Government in the national policy on education (9), sets the aims of primary education as follow:

i. To inculcate permanent literacy and numeracy and ability to communicate effectively;

ii. Lay a sound basis for scientific and reflective thinking;

iii. Give citizenship education as a basis for effective participation in and contribute to the life of the society;

iv. Mould the character and develop sound attitude and morals in the child;

v. Develop in the child the ability to adapt to his changing environment;

vi. Give the child opportunities for developing manipulative skills that will enable him function effectively in the society within the limit of his capacity; and

vii. Provide the child with basic tools for further educational advancement including preparation for trades and craft of the locality.

The million dollar question therefore, is through which medium can the Nigerian child achieve these aims to make learning sequence simple, logical and practical? The obvious answer is through the language of instruction and communication. 


\section{National policy on language education}

The language of instruction in educational institutions in multilingual societies has always been a matter of concern to educators and educational planners. The African situation is aptly captured by Ouadraogo [18], when he asserts that "education and language issues are very complex in Africa because of the multi-ethnic and multi-lingual situations. Nigeria is highly multi-lingual and multi-ethnic, with over 500 indigenous languages spoken within her borders, says Blench [5]. The policy on language education in Nigeria dates back to the colonial era when the Phelps - stocks commission of 1922 emphasized the importance of indigenous languages in the school system. The British advisory committee on native education in tropical African recommended in 1927, that the native languages should serve as medium of instruction in the lower years of primary education.

According to Bamgbose [3], the introduction of formal education and the subsequent adoption of English as the medium of instruction, hindered the exclusive use of indigenous languages as media of instruction at the primary school in Nigeria. However it has been the official policy in Nigeria that the medium of instruction at the lower primary, (the first three years) should be the indigenous language of the child or the language of his/her immediate environment while at the upper primary school, English should be the medium of teaching and the major indigenous language of Hausa, Igbo and Yoruba, should be thought as school subjects. FRN [9].

In his opinion, Awobuluyi [2], asserts that some indigenous languages have been taught in schools since formal western type of education was introduced into Nigeria after her independence in October 1960. A language is a vehicle for a people's culture and a means of maintaining and indefinitely preserving that culture. The implication of this, he continues is that if we are not ultimately to lose our national identity together with our rich indigenous culture, then we must begin to pay much attention to the teaching of indigenous languages more effectively.

\section{Goals in language education}

The goals in language in Nigeria can best be addressed by examining these questions:

a. What kind of language competence do we envisage of the products of our primary school system?

b. What are the language needs of the educated Nigerian?

The above questions can best be considered in the long term and short term stages. To ask what the language needs of the educated Nigerian are today is not a very interesting question because very few persons are contented with the state of affairs. The reason is that, historically, English language has dominated the contemporary Nigerian life style and this is eroding our indigenous cultural norms and values. On one hand, the policy on language education provides a short term solution, given the position of English as the official language of the nation and as the language of inter-ethnic communication among the elite. On the long term view, Nigeria, as an African nation, by her land size and her role in the international scene, must have a foreign language component as well as, well developed and functional indigenous language. Musa [17], Emenanjo [8] and David [7].

The realization of the national education goals of inculcating national unity, right type of values and attitudes for the survival of the individual and the Nigerian society, for instance, depends on a variable like indigenous language. The destructions of language and culture in primary schools are highly counterproductive for any society. Cummins [6] reiterates that at a time when cross-cultural contact is at an all time high in human history, the identities of all societies are evolving. The challenges therefore, are for educators and policy makers to shape the evolution of the national identity in such a way that the right of the primary school children are respected, and the cultural, the linguistic and the economic resources are maximize. To squander the linguistic resources of the nation by discouraging or by depriving children from learning from indigenous language is quite unfortunate says Skutnabb-Kangas [19].

Educationally, instruction in the indigenous language will help the child to understand the concept easily, because he is familiar with their vocabularies. These will be in the interest of primary school children particularly in the area of culture. Language and culture are inseparable, hence through this medium, they will imbibe cultural values that will guide them to uphold the fundamental values of the society. Although English language usage is relevant to our modern living and Nigerian children must learn it in schools, the point still remains that the best medium of starting the child's education is the indigenous language, and it is when a sound linguistic foundation has been laid in it that there can be a change to a foreign one (Musa [16]).

\section{Contemporary issues}

Primary education is a major component in the Universal Basic Education programme in Nigeria. The core objectives being the universalization of access and quality in the delivery of basic education. Others are to inculcate in children

Permanent literacy, numeracy and the ability to communicate effectively. To ensure effective 
achievement of these core objectives English languages is included as one of the core subjects of the basic education curriculum in Nigeria. The contemporary issues now are:

- $\quad$ The multi-lingual challenge.

- Poor policy implementation.

- Teacher quality.

- The problem of curriculum materials.

\subsection{The multi-lingual challenge}

Language is a component of culture along with other elements of values, beliefs and norms. In Nigeria, for instance, the language for education at the basic level has been an issue of debate among scholars for decades. As a multi- lingual nation with at least 400 indigenous languages, Gbenedio [10] noted that only about 65 standardized orthographies and only three major languages of Hausa, Igbo and Yoruba have documented efforts of teacher education. One challenge Musa [17], envisaged, is the lack of adequate vocabulary for most indigenous languages. The problem is accentuated with school subjects like mathematics, sciences and vocational education content areas where words in the local language will not exactly name concept except to describe them. The best education a child can get at the basic level is that given in the indigenous language. Children accordingly to Baker [4], absorb concept much easily in their own familiar languages and can gain a fundamental understanding of them. However, in a second language (L2) situation, in the case of English language in Nigeria, they simply became words that are learnt but not absorbed. Musa [16] reiterates that psychologically, the proper development of the child bound with the uninterrupted use of the language in which he has acquired this first experiences in life, the one in which he dreams and thinks and in which he can effortlessly express his feelings and emotions. To ignore this familiar language and begin to teach him a foreign and unfamiliar language and as soon as he comes to school, is like taking the child away from his home and putting him among strangers.

Language is a spontaneous social activity expressing thoughts, moods and ideas. It is a hallmark of any group of people, community or society. In a multilingual situation as is the case with Nigeria, the challenge is therefore the identification, development and adoption of over 500 languages for the primary schools in the country. There will be the need for a thorough linguistic analysis of these languages in terms of their phonology and grammatical structures. There is the challenge of developing a body of science and technological knowledge which is needed for the products of primary education in Nigeria to favorably compete with their counterparts within the continent of Africa.

\subsection{Poor Policy Implementation}

The use of the child's primary language for the first three years of primary education, as stated in the National Policy on Education (9) is ideal. Concepts will easily be understood and children will gain competence in the use of the language, however, several factors are known to have contributed to the low achievement of the educating goals for primary school in Nigeria. Prominent among them is the large number of indigenous languages within the country and any attempt to compress similar languages to promote one that will represent a cultural area will meet with staff opposition and complaint about marginalization. Another challenge is the low turnout of trained teachers in the various indigenous languages. Yet others are the lack of teaching and learning materials and where they are available, they may not be equitably distributed to urban and rural areas.

\subsection{Teacher Quality}

The issue of language education at the primary school level cannot be exhaustively discussed without making reference to teachers. We lack competently trained teachers to implement education in this regard. A teacher does not qualify to teach a language just because he or she can speak it. A teacher, who himself has difficulties in speaking the language, is not going to succeed in giving his pupils a good command of the spoken language (Ighofuota [11]). It is very common to see many teachers at the primary school level who do not know how to read or write their native languages. They can at least speak it and even at that, with a lot of semantic errors. It must be noted that primary education is a major component of the entire education system in Nigeria. It serves as the foundation for the entire education structure. Therefore, the proper implementation of any curriculum is essentially a function of the quality of the teachers and this, according to Mohammed [14], lends credence to the need to update the knowledge of teachers who are responsible for primary school language education curriculum implementation.

Teachers are the foundations of quality in schools, says Iyobhebhe [12]. It is upon their number, their quality and efficiency that the future of organized education depends. A competent language teacher holds the key to the training of students in language mastery for good performance in school subjects. In Nigeria, teacher education programmes are set to achieve the following:-

- To produce highly motivated, conscientious and efficient classroom teachers for all levels of the educational system. 
- To encourage further the spirit of enquiry and creativity in teachers.

- To help teachers to fit into social life of the community and the society at large and enhance their commitment to national goals.

- To provide teachers with the intellectual and professional background adequate for their assignment and make them adaptable to changing situations.

- To enhance teachers commitment to the teaching profession. FRN (9).

Government's effort is commended here, but there is still a large room for improvement.

\subsection{The problem of curriculum materials}

With the proliferation of publishers like Longman, Evans Brothers, Macmillan and others working in conjunction with the National Educational Research Development Council (NERDC) and the Universal Basic Education Commission (UBEC), course materials and supplementary books in indigenous languages for primary schools, are in short supply. This obviously is because many of the languages do not have orthographies. With the non-availability of these texts, pupils' interest will be poor, teaching will be void of the ability to arouse and sustain pupils' interest and educational goals will be unattainable. Although some indigenous languages have been developed, course books printed and are in use in some states of the country, much still needs to be desired for effective primary schooling.

\section{New direction}

There is the need to develop a good language education programme for primary school level in Nigeria. This is because the effective functionality of the children in their educational or vocational pursuit is dependent on the solid foundation laid at the lower primary school. Teachers should jointly help the pupils to develop competence in the use of their language and that of the immediate environment of schooling. The government has to make adequate funds available for the provision of regular and intensive professional capacity development for classroom teachers in the Universal Basic Education - Federal Government of Nigeria (UBE-FGN) funded in service training scheme. While the training of teachers is on course, experts who can develop the orthography and prepare content materials in the languages should be mobilized. There is no gain saying that instruction in the indigenous languages will in no small help the child to internalize in his own cultural values if one of the aims of educating him is to mould his character and develop sound attitude and morals in him.
However, since language serves as the tool for instruction, there is the need to ensure that those who have the responsibility to teach it or use it to teach other school subjects, are adequately trained and qualify to do so. The selection should be by a combination of certification and aptitude test to avoid the mistake of employing mediocres. Since teaching at the primary school is activity -oriented, well written, colourfully illustrated texts should be distributed freely to primary school children. Supplementary course materials like dictionary, story books and others elementary reading materials, should make the full package of primary education.

In all this, the role of the supervisory ministry of education should be emphasized here. It is necessary that regular supervision of school be made, to set, maintain and improve standards of primary education. Since language is the live wire of the success of primary education, a team of experts in the subject area need to visit schools from time to time to ensure that those whose responsibility it is to teach the subject do so conscientiously and appropriately.

\section{Conclusion}

This paper reflects contemporary issues in primary school language education in Nigeria in a search for new direction. Educating the child is a collective responsibility where all concerned parties take on the challenge to ensure its success. Language holds the key to the success of the teaching and learning process at the primary school level and should therefore be properly developed in the child of today who will become the adult of tomorrow. Competence in the use of indigenous languages at the lower level or English language at the upper level of primary education is the golden keys that will open doors of various fields of study to Nigerian Children. It is needful therefore, that orthographies of the various languages be developed and teachers who will translate them in the classrooms be adequately trained and equipped for the job. Teacher education programmes should be expanded and enriched to make room for the acquisition of appropriate knowledge and skills in language teaching at the primary school level. Since the proper implementation of any curriculum is essentially a function of the quality of teachers, it lends credence to the need to update the knowledge of teachers who are responsible for teaching language at the primary school level.

The current training and re-training of primary school teachers in the six geo-political zones of Nigeria is a good step in the right direction. The executive secretary of the Universal Basic Education Commission, Abuja [14] has explained that the exercise which is in collaboration with the Teacher Education in Sub-Sahara Africa (TESSA), is to 
provide regular professional capacity development opportunities for classroom teachers in UBE-FGN funded in service training scheme for teachers and managers of basic education in Nigeria. It is therefore required that primary school teachers in Nigeria will avail themselves of this opportunity to improve on the required impetus for high teacher effectiveness in the teaching of language at the primarily school level.

\section{References}

[1] Adenipekun, O. (2010): Experts express optimism on language policy in Nigeria. Vanguard Newspaper, August 4. P18.

[2] Awobuluyi, O. (1998). Language Education in Nigeria: Theory, Policy and Practice. Google search.

[3] Bamgbose, A. (1989). "Issues for a model language planning”. Language problems and language planning. Vol. 13(1). $24-34$.

[4] Baker, C. (2000). A parent's and Teacher's guide to Bilingualism. 2nd Edition. Clevedon, England: Multilingual Matters.

[5] Blench, R. (2002). Research on minority Languages in Nigeria. FEL Newsletter 2001 Ognios.

[6] Cummins, J. (2000). Language, Power and Pedagogy: Bilingual Children in Crossfire. Clevedon, England: Multilingual Matters.

[7] David, W. (1999). English Language Teaching: An Integrated Approach. Ibadan Spectrum Books Ltd.

[8] Emenanjo, E.N. (1990). Multilingualism: Minority Language and National Policy in Nigeria. CBL. Delta State Nigeria.

[9] Federal Government of Nigeria, (2004). National Policy on Education. Lagos NERDC Press.

[10] Gbenedio, B.U. (1990). "Problems of Implementing the Nigerian National Language Policy. The Case of Instruction through the Mother tongue at the Lower Primary Classes". Ekiadolor Journal of Education. Vol. June p. 47-58.

[11] Ighofuota, S. (1990). "Education in mother Tongue: Not the Issue". The Observer, Benin City. Ethiope Publishers. March 10 p.2.

[12] Iyobhebhe, A.E. (2005). "Contemporary issues in Primary Science Education teacher Quality in Nigeria: A Search for New Direction”. In Journal of Childhood and Primary Education. Jan. vol. 1 (1) p. 198-202.

[13] Maduewesi, J. and Eguabor, V.O. (2005). "Contemporary Issues in Primary Education”. Journal of Childhood and Primary Education. Jan. vol. 1 (1) p. 1-7.
[14] Mohammed, A.M. (2011). “TESSA Integrated Manual for the Re-training of Teachers (English Language). Adapted for the FGN/UBE - MDGs 2011" Federal teachers Scheme Induction/Orientation workshop. UBEC. Abuja.

[15] Musa, R.J. (1999). "The Problem of Reading Among Secondary School Students: The way forward for better Academic Performance in Schools”. Knowledge Review vol 1(4) May.

[16] Musa, R.J. (2007). Effects of Montessori and Play Methods of Teaching on Academic Achievement of Nursery School Pupils in Language Arts in Edo State. Unpublished Ph.D Thesis. Abraka.

[17] Musa, R.J. (2010). "The Role of Mother Tongue Education in National Development”. In Social Studies and Integrated National Development in Nigeria. Emman Osakwe (Ed) p. $75-82$.

[18] Ouadraogo, R.W. (2000). Language Planning and Language Policies in some Selected West African Countries. Burkina Faso: IICBA.

[19] Skutnabb - Kangas, T. (2000). Linguistics Genocide in Education - or - Worldwide Diversity and Human Rights. Mahwah, N.J. Lawrence Eribaum Associates. 